\title{
Financing Decision as a Mediating Variable Between Capital Structure and Firm Performance
}

\author{
Elsa Imelda ${ }^{1 *}$, Devina Himelda ${ }^{1}$ \\ ${ }^{1}$ Accounting Program, Faculty of Economics and Business, Universitas Tarumanagara, Jakarta, Indonesia \\ *Corresponding author. Email: elsai@fe.untar.ac.id
}

\begin{abstract}
The purpose of this research was to empirically examine the influence of capital structure measured by TotalDebt-Ratio (TDR) toward firm performance measured by Tobin's-Q, with financing decision measured by Retention-Ratio (RR) as a mediating variable. This study used the secondary data obtained from the Indonesia Stock Exchange (IDX). The population of this study is the banking companies listed in IDX for the period of 2016 - 2018. Based on several criteria, 42 banking companies listed in IDX were selected as samples in this study. Data analysis used multiple linear regression with the assistance of EViews 10 program. The Sobel-Test was used to test the significance of the mediating effect. The results of this study indicate that capital structure has a positive and significant effect on firm performance, while financing decision has a negative and significant effect on firm performance. However, financing decision does not significantly mediate the effect of capital structure on firm performance. Company must manage its capital structure in the optimal portion so it can increase company performance. The retained earnings must be used for company development.
\end{abstract}

\section{Keywords: Firm Performance, Capital Structure, Financing Decision}

\section{INTRODUCTION}

Today, the global economy is experiencing a slowdown and turmoil with uncertainty about the direction. The global financial market is also affected by global economic slowdown, which can affect the economies of many countries. A country's economic slowdown can have an impact on company performance, so the company's management needs to make the right decisions in maintaining and improving its performance, thus the company can continue to develop, compete, and last for a long time.

According to [1], a good company performance is characterized by high market value of the company and an increasing company's share price. An increase in share price indicates an increase in the profits and welfare of the shareholders. This provides a positive signal regarding the company's good performance so that it can attract investors to invest in it. The company performance is influenced by several factors, including the composition of the company's capital structure and financing decision. According to [2], the composition of the optimum capital structure does not only make the company survive and develop, but also improves its performance so that it can compete in a competitive business environment. Companies using debt financing in the capital structure can provide a signal that it has a good prospect and performance so that it also has a good ability to pay its debts. However, using debt financing can also mean the opposite way, in which the company gives a signal about its poor performance and the possibility of high bankruptcy.

According to [3], financing decisions are related to financial decisions whether the funds are obtained from internal parties or external parties (both from the money market and the capital market). Financing decisions are closely related to the cost of capital considerations. The company's performance can decrease, if the cost of capital to be paid is too large compared to the benefits obtained from the selected financing method.

This study aimed to reveal the effect of capital structure on company performance. The role of financing decision as a mediating variable was also tested whether it is able to mediate the effect of capital structure on company performance. The research on company performance continues in order to find out whether these factors are still relevant in influencing company performance and to provide information about the aspects that can help managers improve the company performance.

\section{THEORETICAL REVIEW}

In Signaling Theory, [4] explained that the financial statements issued by the company indirectly become a signal given by the company to the external parties. Those signals in financial statements can be used to make certain decisions. The receiver of the signal takes action according to the signal received. 
According to [5], firm performance shows the company's ability to make profit from assets, equity, and debt. According to [6], firm performance is an actual result that measures the achievement of company goals. Company performance can be measured in terms of finance. According to [7], financial performance emphasizes the variables related to financial statements.

According to [8], the capital structure is the mix of debt and equity used to finance and manage the assets. The capital structure is a mix of debt, preferred stock, and general equity used to fund the company assets. According to [9], capital structure is a mixture of long-term debt and equity managed by the company. According to [10], capital structure is how a company finances its business activities, which consists of debt and equity sold to the investors and owners. The research conducted by [11] explained that there is a positive influence of capital structure on firm performance. The research conducted by [2] and [12] explains that there is a negative influence of capital structure on company performance.

According to [3], financing decision is related to the management's decisions to get funds from both the money market and capital market. According to [13], financial decisions regarding the selection of sources of funds to purchase the company assets. The research conducted by [14] explained that financing decision does not have a significant effect on company performance. Meanwhile, the research conducted by [13] and [15] explained that financing decision has a significant and negative effect on company performance. In addition, the research conducted by [11] explained that financing decision has a significant and positive effect on company performance. Furthermore, the research conducted by [11] also stated that financing decision can mediate the effect of capital structure on company performance.

Based on theoretical studies and previous researches, the framework and research hypotheses used in this study are explained in the next section. The capital structure is a mixture of company's capital consisting of short-term debt, long-term debt, preference shares, and common shares. The increase in corporate debt, such as loans, provides additional cash to finance the company's operational activities. The funds obtained are then used optimally to improve the company performance. Managers are forced to improve the company performance, because the company has to pay-off the debts at maturity and also pay the interest on debt. An improved company performance can be a good signal for investors and shareholders regarding the condition of the company.

$\mathrm{H}_{1}$ : Capital structure has a positive effect on company performance.

A financing decision is a decision to obtain a source of funds to finance the purchase of assets. When managers can make the right financing decision, the benefits obtained will be greater than the costs sacrificed so that the company performance will be better. One of the ratios used to measure financing decision is the Retention-Ratio (RR). If the management decides to retain most or all of the company's profits and only distributes a small amount of dividend or does not distribute the dividend at all, this can be a signal to external parties that the company's performance is in a state, which is not good.

$\mathrm{H}_{2}$ : The financing decision has a negative effect on company performance.

Companies that have a high level of debt in the composition of their capital structure need the funds in order to meet their debt principal repayment obligations and interest expenses on the debt. This causes the company to hold a large part or even all of its profits and not distribute it in the form of dividends to shareholders. The retained earnings can be used by the manager to pay-off the company's debt. With the information asymmetry factor, the company's decision to retain most or all of its profits and not to be distributed in form of dividends is a signal to external parties that the company is in poor performance, so it has to withstand a lot of company profits and is unable to distribute dividends to shareholders.

$\mathrm{H}_{3}$ : Financing decision mediates the effect of capital structure on company performance.

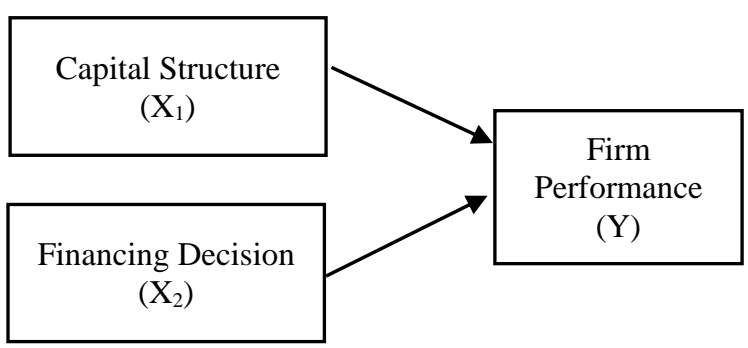

Figure 1 Conceptual Framework Model 1

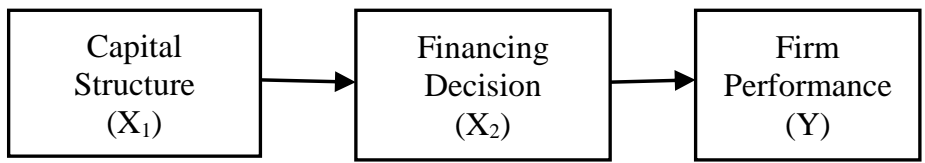

Figure 2 Conceptual Framework Model 2

\section{METHODOLOGY}

The object of this research is capital structure as measured by Total-Debt-Ratio (TDR) as the independent variable, financing decision as measured by Retention Ratio $(R R)$ as the mediating variable, and company performance as measured by Tobin's- $Q$ as the dependent variable. The subjects in this study were banking companies listed in the Indonesia Stock Exchange (DIX) in the period of 2016 2018. The data in this study are secondary data derived from the banking-company financial reports downloaded on the official website of IDX.

The sample in this study was analyzed using multiple regression analysis and processed using the EViews 10 program. The sampling process was carried out by nonprobability sampling and using the purposive-sampling technique to obtain a representative sample based on the 
criteria, including: (1) Banking companies that have been and remain listed in the IDX during 2016-2018; (2) The financial reports were audited by a Public Accountant; (3) Financial and Annual Reports are available in full for the 2016-2018 period in the IDX; (4) Financial Reports use the Rupiah currency in financial reporting; (5) Financial statements began on January $1^{\text {st }}$ and ended on December $31^{\text {st }}$; (6) The company did not experience delisting during the observation period and did not conduct an IPO during the 2017-2018 period. Based on the predetermined criteria, 42 banking companies met the criteria with a total of 126 data. Then, the outlier test was carried-out to eliminate extreme data so that the sample data to be used was only 113 data.

Table 1 The Summary of Variable Operationalizations

\begin{tabular}{|c|c|c|}
\hline Variable & Size & Scale \\
\hline $\begin{array}{c}\text { Company } \\
\text { Performance }\end{array}$ & Total Market Value of Firm & Ratio \\
\hline $\begin{array}{c}\text { Capital } \\
\text { Structure }\end{array}$ & $\frac{\text { Total Liability }}{\text { Total Assets }}$ & Ratio \\
\hline $\begin{array}{c}\text { Financing } \\
\text { Decision }\end{array}$ & $\frac{\text { Net Income }- \text { Dividend }}{\text { Net Income }}$ & Ratio \\
\hline
\end{tabular}

\subsection{Statistical-Test Results}

Based on the results of data panel processing by performing the Chow Test and Hausman Test, the best model used in this study is the random-effect model. Then, we performed the classical-assumption test which includes the normality test, autocorrelation test, multicollinearity test, and heteroscedasticity test. The results of normality test generate the probability-value of 0.05 . This rate is greater than the limit of significance level of 0.05 or $5 \%$, then the residual in this study had normal distribution, thus qualify the normality test. The results of the autocorrelation test refer to [16], in which if the Durbin-Watson value in the test states the result between -2 and 2, then there is no autocorrelation in this study. The Durbin-Watson value obtained is 1.705771 , so it can be concluded that there is no autocorrelation in this study. The results of multicollinearity test showed the correlation between capital structure and financing decision of 0.070312 , whereas this value is less than 0.90 , so it can be concluded that there is no multicollinearity problem in this study. Meanwhile, the results of heteroscedasticity test using the Harvey test show that the probability value of capital structure is 0.0952 and the probability value of investment decisions is 0.4283 , so it can be concluded that there is no heteroscedasticity problem in this study.

The descriptive statistics results in the mean, maximum, minimum, and standard deviation values. The descriptive statistics of the company performance variable have a mean value of 1.162523 , a standard deviation of 0.159711 , the maximum value of 1.571670 , and the minimum value of 0.631450 . The mean value which is higher than one means that averagely the company has performed well. The descriptive statistics of the capital structure variable have a mean value of 0.817015 , a standard deviation of 0.126322 , the maximum value of 0.926870 , and the minimum value of 0.075790 . The average value means that the average company using debt is $81.7015 \%$ in the composition of its capital structure. The descriptive statistics of the financing decision variable has a mean value of 0.871206 , a standard deviation of 0.194486 , the maximum value of 1.000000 , and a minimum value of 0.248760 . The average firms hold $87.1206 \%$ of the profits and the rest is distributed in form of dividends.

\subsection{Multiple Regression Test}

Multiple regression test aims to measure the influence of the independent variables on the dependent variable. A significance level of $5 \%$ or 0.05 was used in the multiple linear regression analysis. The multiple linear regression equation used in this study is as follow:

$$
T Q=1.180734+0.331876 T D R-0.331749 R R
$$

The results of the t-statistical test are presented in Table 2 below:

Table 2 The Results of $t$-Test

\begin{tabular}{|c|c|c|c|c|}
\hline Variable & Coefficient & Std. Error & t-Statistic & Prob. \\
\hline C & 1.180734 & 0.111895 & 10,55215 & 0.0000 \\
\hline TDR & 0.331876 & 0.107448 & 3.088716 & 0.0025 \\
\hline RR & -0.331749 & 0.073504 & -4.513373 & 0.0000 \\
\hline
\end{tabular}

Source: Data Analysis Results (2020)

Capital structure variable has a p-value of 0.0025 , whereas this value is less than the level of significance that has been set. The beta coefficient of the capital structure variable is 0.331876 , so it can be concluded that there is a significant and positive influence of capital structure on company performance. The financing decision variable has a $p$-value of 0.0000 , whereas this value is less than the predetermined significance level. The beta coefficient of the investment decision variable is -0.331749 . Thus, it can be concluded that there is a negative and significant influence of financing decision on company performance.

The mediation test aims to determine whether the mediating variable can mediate the effect of the independent variable on the dependent variable. Table 3 below shows the test results of the equation regarding the effect of the independent variable on the mediating variable.

Table 3 The Results of $t$-Test

\begin{tabular}{|c|c|c|c|c|}
\hline Variable & Coefficient & Std. Error & t-Statistic & Prob. \\
\hline C & 0.899056 & 0.114903 & 7.824494 & 0.0000 \\
\hline TDR & -0.034271 & 0.136945 & -0.250253 & 0.8029 \\
\hline
\end{tabular}

Source: Data Analysis Results (2020)

The beta coefficient in the direct effect of capital structure on company performance (now symbolized as $\mathrm{p}_{1}$ ) in Table 2 is 0.331876 , while the beta coefficient in the effect of 
capital structure on financing decision (now symbolized as $\mathrm{p}_{2}$ ) in Table 3 is -0.034271 . The beta coefficient in the effect of financing decision on company performance (now symbolized as $\mathrm{p}_{3}$ ) in Table 2 is -0.331749 . The direct effect of capital structure on company performance is 0.331876 , and the indirect effect of capital structure on company performance can be obtained by multiplying $\mathrm{p}_{2}$ and $\mathrm{p}_{3}(=-0.034271 \times-0.331749)$, which results the value of 0.011369 . The total effect on the capital structure is equal to $0.331876+0.011369=0.343245$. This result indicates that the value of total effect is higher than the value of direct effect. However, due to the insignificant effect of capital structure on financing decision, this result means that financing decision is not able to mediate the effect of capital structure on company performance.

Overall significance test or the F-statistics test has the aim to test the overall and simultaneous effect of the independent variables on the dependent variable, and to determine whether the regression model is fit-for-use in this research. In the overall significance test, a significance level of 0.05 was set. If the value of Prob (F-Statistic) shows a value less than 0.05 , the regression model is considered feasible and the independent variables, including the mediating variable, simultaneously influence the dependent variable, and vice versa. Based on the test results, the Prob (F-Statistics) value obtained is 0.000001 , whereas this value is less than 0.05 . So, it can be concluded that the independent variable and the mediating variable simultaneously affect the dependent variable, and this regression model is feasible-to-use.

The coefficient-of-determination (CD) test or the Adjusted $R$-square test aims to determine the ability of the independent variable (capital structure) to explain the dependent variable (company performance) including the mediating variable (financing decision). The result of $\mathrm{R}^{2}$ test with a value of 0.207983 means that as much as $20.7983 \%$ of the variation in the dependent variable (company performance) can be explained by the independent variable including the mediating variable, while the remaining $79.2017 \%$ of the variation in company performance is explained by other variables not included in this study.

\section{DISCUSSIONS}

In this study, it can be concluded that capital structure has a positive and significant effect on company performance. From the conclusions obtained, $\mathrm{H}_{1}$ which mentions that capital structure has a positive effect on company performance was not rejected, or in other word, the first hypothesis was accepted. The capital structure has a significant effect on company performance, because the increase in corporate debt, such as loans, provides additional cash to finance the company's operational activities. The funds obtained are used optimally to improve the company performance. Managers are forced to improve the company performance, because the company has to payoff its debts at maturity as well as paying the interest on debt. The improved company performance can be a good signal for investors and shareholders regarding the condition of the company. The results of this research are in line with [11], which explained that capital structure has a positive effect on company performance. This result is not in line with [2] and [12], which explained that capital structure has a negative effect on company performance. Financing decision negatively and significantly affects company performance. From the conclusion obtained, then $\mathrm{H}_{2}$, which mentions that financing decision has a negative effect on company performance, was not rejected, or in other word, the second hypothesis was accepted. The financing decision has a significant effect on company's performance, because if a company holds too much profit balance, then the dividends distributed to the shareholders will be less or even not distributed at all. By not forgetting the factor of asymmetry of information between the company's internal and external parties, if the company's managers make financing decision that is less precisely whereas the majority of the balance of corporate profits are hold and not being shared, the shareholders may interpret those signals as the company performance is poor as well. This can be interpreted by external parties that the company is in poor performance and requires a lot of additional funds, including those from retained earnings. Reducing the amount of retained earnings and distributing it in the form of dividends to shareholders can be a signal that the company's performance is in good shape. Because of having good performance, the company does not need to hold all the profit balances as additional funds to finance its operational activities, and even the company is able to distribute the dividends to its shareholders. The result of this study is in line with the research conducted by [13] and [15], which explained that financing decision has a negative effect on company performance. The result of this study is inconsistent with [11], which described that the financing decision has a positive impact on company performance.

Financing decision is not able to function as a mediator in the relationship between the capital structure and company performance. From the conclusion obtained, then $\mathrm{H}_{3}$ which says that financing decision mediates the effect of capital structure on company performance, was rejected. This is because the capital structure has a negative and insignificant effect on financing decision. A high level of debt does not guarantee a company to hold more retained earnings and a low level of debt also does not guarantee that a company holds less retained earnings. In determining financing decision, company managers do not look at the percentage of debt or equity held in the composition of the company's capital structure. Company managers may consider the profit earned by the company, how much earnings will be retained by the company and how much earnings will be distributed in form of dividends to shareholders. Because the capital structure has no significant effect on financing decision, the company's performance has not changed. The result of this study is not in line with research conducted by [11] which explains that financing decision can mediate the effect of capital structure on company performance. 


\section{CLOSING}

Conclusions of this research are: First, company must manage its capital structure in the optimal portion, so it can increase company performance. Company must use the debt from creditor to manage its assets and generate profits or earnings. Second, the company must manage its earnings and make the right decision regarding the earnings, either to be retained or to be distributed. The retained earnings must be used for company development.

This study is inseparable from limitations, because there are things that cannot be done during the study. The research sample is only limited to the banking companies listed in IDX with a span-time of 3 years (2016 to 2018). In addition, the variables used in this study was also limited to a few variables only. This study only has one independent variable, namely capital structure and one mediating variable, namely the financing decision. Due to the limitations of this study, there are several suggestions that can be given for further research. For further research, it is hoped that it can add other factors that can affect company performance that are not used in this study. Further research is also expected to increase the period of observation in a longer period of time so that the results obtained are better able to describe the real situation. In addition, it is hoped that it will not only focus on only banking companies, but can add companies in other sectors outside of banking companies.

Managers and shareholder also can focus on the capital structure and financing decision in predicting firm performance. This has been proven around $20.8 \%$ effect of capital structure and financing decision on firm performance. The company must have a good capital structure, but neither too much debt nor too small debt.

\section{REFERENCES}

[1] Dahlan, F., \& M. Suwandi. (2016). Pengaruh Keputusan Investasi terhadap Nilai Perusahaan Jasa Perbankan yang Terdaftar di Bursa Efek Indonesia. Akuntansi Peradaban, 2, 64-88.

[2] MW Birru (2016). The Impact of Capital Structure on Financial Performance of Commercial Banks in Ethiopia. Global Journal of Management and Business Research, 16 (8).

[3] A. Afzal \& Rohman, A. (2012). Pengaruh Keputusan Investasi, Keputusan Pendanaan, dan Kebijakan Dividen terhadap Nilai Perusahaan. Diponegoro Journal of Accounting, 1, 1-9.

[4] M Spence (1973). Job Market Signaling. The Quarterly Journal of Economics, 87, 355-374.

[5] K A Fachrudin (2011). Analisis Pengaruh Struktur Modal, Ukuran Perusahaan, dan Agency Cost terhadap Kinerja Perusahaan. Jurnal Akuntansi dan Keuangan, 13, 37-46.
[6] P J Richard, Devinney, TM, Yip, GS, \& Johnson, G. (2009). Measuring Organizational Performance: Towards Methodological Best Practice. Journal of Management, 35, 718-804.

[7] A Y Almajali, AY, Alamro, SA, \& Al-Soub, YZ (2012). Factors Affecting the Financial Performance of the Jordanian Insurance Companies Listed at the Amman Stock Exchange. Journal of Management Research, 4, 266-289.

[8] E F Brigham, EF, \& Houston, J.F. (2014). Essentials of Financial Management, $3^{\text {rd }}$ Edition. Singapore: Cengage Learning.

[9] L J Gitman, \& Zutter, CJ (2015). Principles of Managerial Finance, 14th Edition. Essex: Pearson. [10] R Brooks (2013). Financial Management Core Concepts, $2^{\text {nd }}$ Edition. Essex: Pearson.

[10] R Brooks (2013). Financial Management Core Concepts, 2 nd Edition. Essex: Pearson.

[11] Y Shahwan (2018). The Mediating Effect of Investment Decisions and Financing Decisions on the Influence of Capital Structure against Corporate Performance: Evidence from Jordanian Listed Commercial Banks. Academy of Accounting and Financial Studies Journal, 22 (6).

[12] L W Mwangi, Macau, MS, \& Kosimbei, G. (2014). Relationship between Capital Structure and

Performance of Non-Financial Companies Listed in the Nairobi Securities Exchange, Kenya. Global Journal of Contemporary Research in Accounting, Auditing and Business Ethics, 1(2), 72- 90.

[13] H S Cahyono, \& Sulistyawati, AI (2016). Keputusan Investasi, Keputusan Pendanaan dan Kebijakan Dividen sebagai Determinan Nilai Perusahaan. Akuisisi, 12, 39-53.

[14] Y Efni (2017). The Mediating Effect of Investment Decisions and Financing Decisions on the Effect of Corporate Risk and Dividend Policy against Corporate Value. Investment Management and Financial Innovations, 14 (2), 27-37.

[15] Z A Alslehat \& Altahtamouni, FR (2014). The Causal Relationship between Financial Decisions and Their Impact on Financial Performance. International Journal of Academic Research in Accounting, Finance and Management Sciences, 4, 72-80.

[16] D Sunyoto (2016). Metodologi Penelitian Akuntansi. Bandung: PT Refika Aditama. 